\title{
Przekazanie przez uczelnię nieruchomości w posiadanie zależne a stosowanie zwolnienia podatkowego. Glosa częściowo krytyczna do wyroku Wojewódzkiego Sądu Administracyjnego w Gorzowie Wielkopolskim z dnia 20 listopada 2019 r., I SA/Go 668/19'1
}

The transfer of interest in property by a university as dependent possession and the application of tax exemptions. Gloss on the decision of the Voivodeship Administrative Court in Gorzów Wielkopolski of 20 November 2019, I SA/GO 668/19 Передача высшим учебным заведением недвижимости в зависимое владение а применение налогового освобождения. Частично критический комментарий по решению Воеводского Административного суда в городе Гожув-Велькопольский от 20 ноября 2019 года, I SA/Go 668/19

\author{
MARZENA ŚWISTAK \\ Dr, Uniwersytet Marii Curie-Skłodowskiej w Lublinie \\ e-mail: marzena.swistak@poczta.umcs.lublin.pl, https://orcid.org/0000-0002-3910-6019
}

PAWEŁ SMOLEŃ

Dr hab., prof. Katolickiego Uniwersytetu Lubelskiego Jana Pawła II e-mail: pawel.smolen@kul.pl, https://orcid.org/0000-0001-6607-3446

\begin{abstract}
Streszczenie: Ustawa z dnia 12 stycznia 1991 r. o podatkach i opłatach lokalnych przewiduje zwolnienie z opodatkowania nieruchomości należących do uczelni i innych jednostek. Zwolnienia te mają charakter podmiotowy. W każdym z tych przypadków zwolnienie nie dotyczy przedmiotów opodatkowania zajętych na działalność gospodarczą. Niestety ustawa podatkowa nie precyzuje tego pojęcia. Ponadto dla właściwego zastosowania zwolnień konieczne jest uwzględnienie przepisów ustawy Prawo przedsiębiorców oraz ustawy 2.0. Wyłaniające się na tym tle trudności znalazły praktyczne odzwierciedlenie w sporze zawisłym przed Wojewódzkim Sądem Administracyjnym w Gorzowie Wielkopolskim w kontekście przekazania przez uczelnię nieruchomości w posiadanie zależne spółce celowej. W przygotowanej glosie do wyroku z dnia 20 listopada 2019 r., I SA/Go 668/19, w części podzielono tok narracji merytorycznej sądu, przedstawiając jednocześnie odmienną propozycję rozstrzygnięcia problemu.
\end{abstract}

Słowa kluczowe: podatek od nieruchomości, zwolnienie z opodatkowania, uczelnia, transfer wiedzy i technologii do gospodarki

Summary: The Municipal Charges Act of 12 January 1991 stipulates tax exemptions concerning property tax for universities and other higher education institutions. Nevertheless, the aforementioned Act may exercise the right for tax exemption under certain conditions. The real estate possessed by the university must not be occupied for business activity. Unfortunately, the Municipal Charges Act does not define the phrase - "occupied for business activity". What is more, for the proper interpretation and practice of the exemption from tax, the 
regulation of the Business Act and the Law 2.0 should be applied. The dilemma concerning the aforementioned Act was met by the Voivodeship Administrative Court in Gorzów Wielkopolski. The Authors of the gloss on the decision of the Voivodeship Administrative Court in Gorzów Wielkopolski of 20 November 2019, I SA/Go 668/19, agreed with the main trend of the court's decision, underlining the other way of the argumentation as well.

Key words: property tax, tax exemption, university, knowledge and technology transfer

Резюме: Закон от 12 января 1991 года «О местных налогах и сборах» предусматривает налоговые льготы для недвижимости, принадлежащей высшим учебным заведениям и другим организациям. Эти исключения носят субъектный характер. В каждом из этих случаев освобождение не применяется к объектам налогообложения, занятым под предпринимательскую деятельность. К сожалению, Закон о налогообложении не уточняет это понятие. Кроме того, для правильного применения исключений необходимо учитывать положения Закона о предпринимательстве и Закона 2.0. Возникающие в этом контексте трудности нашли практическое отражение в споре, рассматриваемом в Воеводском Административном суде в городе Гожув-Велькопольский в связи с передачей вузом недвижимого имущества в зависимое владение компании специального назначения. В подготовленном комментарии к судебному решению от 20 ноября 2019 года, I SA/Go 668/19, авторы частично разделяют содержательное изложение суда, но при этом представляют иное предложение по решению проблемы.

Ключевые слова: налог на недвижимость, освобождение от уплаты налогов, высшее учебное заведение, трансфер знаний и технологий в экономику

\section{Wstęp}

Zasadniczo $\mathrm{w}$ polskim porządku prawnym obowiązuje zwolnienie $\mathrm{z}$ opodatkowania nieruchomości należących do jednostek szkolnictwa wyższego wskazanych w ustawie z dnia 12 stycznia $1991 \mathrm{r}$. o podatkach i opłatach lokalnych². W aktualnym stanie prawnym zwolnienie to obejmuje różnorodne podmioty prowadzące szeroko rozumianą działalność badawczo-dydaktyczną. Należą do nich m.in. uczelnie, federacje podmiotów systemu szkolnictwa wyższego i nauki czy instytuty badawcze. W każdym z tych przypadków zwolnienie nie dotyczy przedmiotów opodatkowania zajętych na działalność gospodarczą. Zwolnienia te mają charakter podmiotowy i obejmują tylko te podmioty, które zostały w ustawie wskazane wprost. Problematyka ta ma dużo szerszy kontekst merytoryczny. Można mówić o swoistym "systemie podatkowego wsparcia” dla wymienionych jednostek szkolnictwa wyższego. Analogiczne regulacje występują w podatku rolnym i podatku leśnym ${ }^{3}$. Samo założenie wydaje się być potrzebne i w pełni uzasadnione. Szczegółowa analiza obowiązujących rozwiązań nasuwa jednak szereg zastrzeżeń, które mogą podawać w wątpliwość skuteczność przyjętych instrumentów polityki podat-

2 Tekst jednolity: Dz. U. z 2019 r. poz. 1170.

3 Art. 12 ust. 2 ustawy z dnia 15 listopada 1984 r. o podatku rolnym (tekst jednolity: Dz. U. z 2020 r. poz. 333 z późn. zm.) oraz art. 7 ust. 2 ustawy z dnia 30 października 2002 r. o podatku leśnym (tekst jednolity: Dz. U. z 2019 r. poz. 888 z późn. zm.). 
kowej. Rysujące się dylematy obejmują kilka obszarów. Już na wstępie wyłaniają się one na gruncie samej ustawy o podatkach i opłatach lokalnych, następnie narastają w świetle analizy rozwiązań przyjętych w innych ustawach pozapodatkowych.

Przede wszystkim należy podkreślić, iż zwolnienia te jako zwolnienia podmiotowe mogą być zastosowane wyłącznie jeśli dana instytucja posiada status podatnika. Oznacza to, że nie obejmuje to przypadków, gdy grunty lub budynki są wykorzystywane na cele uczelni jedynie na podstawie umowy najmu lub dzierżawy zawartej z innym podmiotem, będącym właścicielem tych nieruchomości. W polskim porządku prawnym podatnikiem jest wówczas ten właśnie podmiot. Wyjątek stanowią jedynie nieruchomości należące do Skarbu Państwa lub jednostek samorządu terytorialnego. W takim przypadku jednostki szkolnictwa wyższego będące posiadaczem zależnym zachowują status podatnika w podatku od nieruchomości, a tym samym są uprawnione do skorzystania z preferencji podatkowej (oczywiście pod warunkiem, że nieruchomości te nie zostaną zajęte na prowadzenie działalności gospodarczej) $)^{4}$.

Istotne znaczenie posiada w tym kontekście również sformułowanie „zwolnienie nie dotyczy przedmiotów opodatkowania zajętych na działalność gospodarczą”. Ogólny sens tego wyłączenia wydaje się być jasny. Ustawodawca obejmuje zwolnieniem tylko tzw. działalność statutową jednostek szkolnictwa wyższego. Wypada jednak zwrócić uwagę na nieostry charakter zwrotu „zajęcia na działalność gospodarczą", którego ustawa podatkowa nie precyzuje. Co więcej, rozróżnia dwa pojęcia: „związanie z działalnością gospodarczą” (jako określoną cechę nieruchomości stanowiącą przedmiot opodatkowania) oraz wspomniane „zajęcie na prowadzenie działalności gospodarczej” (jako cechę nieruchomości uzasadniającą wyjątek od zwolnienia podatkowego).

Zarysowana charakterystyka aktualnej regulacji zwolnień w podatku od nieruchomości znalazła swe praktyczne odzwierciedlenie także w sporze zawisłym przed Wojewódzkim Sądem Administracyjnym w Gorzowie Wielkopolskim w związku z przekazaniem przez uczelnię nieruchomości w posiadanie zależne spółce celowej. Niewątpliwie należy podzielić główny nurt rozważań sądu. Jednakże zdaje się, że w przypadku formułowania zaleceń dla organu podatkowego do ponownego badania sprawy sąd dokonał nieco powierzchownej analizy (i w konsekwencji argumentacji), w szczególności na tle odniesienia się do regulacji ustawy 2.0. Dotyczy to przede wszystkim konieczności ustalenia, czy spółka celowa utworzona w wyniku komercjalizacji prowadzi działalność gospodarczą na nieruchomości uczelni, a tym

4 Szerzej zob. L. Etel, R. Dowgier, G. Liszewski, B. Pahl, Podatki i opłaty lokalne. Komentarz, Warszawa 2020. 
samym czy nieruchomość ta jest zajęta na działalność gospodarczą. Rozstrzygnięcie tej właśnie kwestii stanowi klucz do sformułowania tezy o możliwości (lub nie) zastosowania zwolnienia dla uczelni. W niniejszej glosie podjęto próbę dokonania interpretacji przepisów podatkowych w szerszym kontekście niż uczynił to Wojewódzki Sąd Administracyjny. W naszej ocenie niezbędne wydaje się spojrzenie przez pryzmat przepisów pozapodatkowych (tu: ustawy $2.0^{5}$ i Prawa przedsiębiorców $^{6}$ ) oraz wykazanie ścisłych związków między nimi.

\section{Przedstawienie stanu sprawy}

Glosowany wyrok WSA w Gorzowie Wielkopolskim z dnia 20 listopada 2019 r., I SA/Go 668/19, ${ }^{7}$ został wydany na kanwie sprawy dotykającej ważkiego dla podatników zagadnienia zwolnienia podatkowego uczelni w kontekście przekazania przedmiotu opodatkowania w posiadanie zależne spółce $\mathrm{z}$ ograniczoną odpowiedzialnością (spółce celowej)․ W zaistniałym stanie faktycznym spółka celowa, w której uczelnia była jedynym udziałowcem, zgodnie z założeniami projektu realizowanego w ramach Regionalnego Programu Operacyjnego (transfer badań, nowoczesnych technologii i innowacji ze świata nauki do przedsiębiorców) zobligowana była zawrzeć z uczelnią umowę użyczenia. Nabyty lub wytworzony w ramach projektu majątek przekazany do używania spółce celowej w ramach zawartej umowy miał być wykorzystywany wyłącznie do świadczenia usług na warunkach preferencyjnych na rzecz przedsiębiorców. Wynagrodzenie spółki uzyskane w projekcie miało być ustalone na minimalnym poziomie gwarantującym możliwość prowadzenia działalności objętej projektem, nieprzekraczającym wysokości uzasadnionych kosztów jej działalności niepokrytych uzyskanymi przychodami. Jednocześnie, pomimo zawarcia ze spółką umowy użyczenia, uczelnia nie utraciła możliwości bezpośredniego wykorzystywania tych nieruchomości i znajdującej się w nich infrastruktury badawczej i naukowej w określonym miesięcznie wymiarze godzin. Nieruchomości stanowiące przedmiot użyczenia miały być regularnie wy-

5 Ustawa z dnia 20 lipca 2018 r. - Prawo o szkolnictwie wyższym i nauce, tekst jednolity: Dz. U. z 2020 r. poz. 85 z późn. zm. (dalej: ustawa 2.0).

6 Ustawa z dnia 6 marca 2018 r. - Prawo przedsiębiorców, tekst jednolity: Dz. U. z 2019 r. poz. 1292 $\mathrm{z}$ późn. $\mathrm{zm}$.

7 LEX nr 2749256.

8 Dalej: spółka celowa. 
korzystywane przez pracowników i studentów uczelni do prowadzenia działalności badawczej i naukowej, a zatem realizowania podstawowych zadań uczelni.

Uczelnia przedstawiła organowi wydającemu interpretację indywidualną stanowisko, że powinna być ona uprawniona do skorzystania ze zwolnienia od podatku od nieruchomości na podstawie art. 7 ust. 2 pkt 1 ustawy o podatkach i opłatach lokalnych ${ }^{9}$, gdyż nie doszło do realizacji przesłanki wyłączającej możliwość skorzystania ze zwolnienia podatkowego, tj. „zajęcia na działalność gospodarczą". Jak podnosiła, nieruchomości nie były wydzielone i wykorzystywane wyłącznie na prowadzenie działalności gospodarczej, bowiem jednocześnie na tych samych obiektach, zgodnie z określonym harmonogramem, prowadzona była również działalność statutowa. Uczelnia powołała się przy tym na orzecznictwo innych sądów administracyjnych i poglądy doktryny ${ }^{10}$. Odwołując się do słownikowego rozumienia pojęcia „zajęcie”, wskazała, że o zajęciu nieruchomości na prowadzenie działalności gospodarczej można mówić dopiero wtedy, gdy wykonywanie działalności gospodarczej wyklucza całkowicie prowadzenie na danej nieruchomości przez uczelnię działalności innej niż działalność gospodarcza ${ }^{11}$. Obowiązek zapłaty podatku od nieruchomości za grunt i budynki będące własnością uczelni powstałby dopiero w sytuacji, gdy grunt ten byłby stale zajęty na prowadzenie działalności gospodarczej w sposób wyłączający możliwość prowadzenia choćby w ograniczonym zakresie przez uczelnię działalności statutowej.

Uczelnia podkreślała także, że w świetle przepisów ustawy Prawo o szkolnictwie wyższym i nauce ${ }^{12}$ nie ma wątpliwości, iż w szczególności świadczenie usług badawczych oraz transfer wiedzy i technologii do gospodarki mieści się w katalogu zadań podstawowych, a w konsekwencji nie stanowi działalności gospodarczej. Argumentowano, że istotne jest to, że umowa użyczenia została zawarta wyłącznie w celu umożliwienia realizacji obowiązków uczelni wynikających z umów o dofinansowanie, a polegających na transferze do gospodarki udzielonej pomocy. Działalność spółki celowej stanowi więc formę komercjalizacji pośredniej ${ }^{13}$. Podniesiono, że

9 Ustawa z dnia 12 stycznia 1991 r. o podatkach i opłatach lokalnych, tekst jednolity: Dz. U. z 2019 r. poz. $1170 \mathrm{z}$ późn. zm.

10 Tak L. Etel, S. Presnarowicz, Podatki i opłaty samorzadowe. Komentarz, Warszawa 2005 [wyd. el. LEX]; wyrok WSA w Poznaniu z dnia 15 grudnia 2010 r., III SA/Po 449/10, LEX nr 757217; wyrok WSA w Białymstoku z dnia 5 marca 2007 r., I SA/Bk 14/07, LEX nr 518301; wyrok WSA we Wrocławiu z dnia 3 października 2017 r., I SA/Wr 768/17, LEX nr 2391668.

11 Zgodnie z definicją podawaną przez Stownik języka polskiego zająć oznacza zapełnić sobą lub czymś jakąś przestrzeń lub powierzchnię, Stownik języka polskiego [online], https://sjp.pwn.pl/sjp/ zajac;2542516.html [dostęp: 9.10.2020 r.].

12 Art. $425 \mathrm{w}$ zw. $\mathrm{z}$ art. 11.

13 Art. 149 ust. 1 ustawy 2.0. 
utworzona spółka celowa nie działa w celu osiągnięcia zysku, ponieważ świadczy usługi poniżej cen rynkowych, a z osiągniętych przychodów pokrywa koszty swojej działalności.

Organ nie podzielił jednak poglądów uczelni i wskazał, że w opisanej sytuacji uczelnia nie jest uprawniona do skorzystania ze zwolnienia podatkowego. Podkreślił, że ze zwolnienia korzystają uczelnie, jeśli określona nieruchomość nie jest zajęta na prowadzenie działalności gospodarczej, niezależnie od tego, kto taką działalność prowadzi. Nie zaaprobowano również poglądu uczelni o konieczności zaistnienia przesłanki wyłączności w prowadzonej działalności gospodarczej, której wypełnienie miałoby dopiero warunkować ziszczenie się warunku „zajęcia na działalność gospodarczą". Wskazano, że intensywność wykorzystania nieruchomości na cele działalności gospodarczej ani też występowanie, obok gospodarczego wykorzystania, także innego celu (w tym przypadku prowadzenie działalności naukowej i badawczej), nie może stanowić podstawy do utrzymania zwolnienia podatkowego ${ }^{14}$.

Uczelnia zaskarżyła wydaną interpretację i wniosła skargę do Wojewódzkiego Sądu Administracyjnego w Gorzowie Wielkopolskim. Zarzuciła naruszenie przepisów prawa procesowego, które miało wpływ na rozstrzygnięcie sprawy, oraz przepisu prawa materialnego - art. 7 ust. 2 pkt 1 ustawy o podatkach i opłatach lokalnych, polegające na dokonaniu jego błędnej wykładni, które prowadziło do uznania, że uczelnia publiczna nie korzysta ze zwolnienia od podatku od nieruchomości. W skardze w większej części powtórzono argumentację przedstawioną wcześniej organowi. Dodatkowo uwypuklono, że zgodnie z art. 425 ustawy 2.0 wykonywanie przez uczelnię zadań, w tym transfer wiedzy i technologii do gospodarki, nie stanowi działalności gospodarczej w rozumieniu przepisów ustawy z dnia 6 marca 2018 r. - Prawo przedsiębiorców ${ }^{15}$. Zatem organy podatkowe po wejściu w życie ustawy 2.0 powinny zweryfikować sposób oceny przesłanek zwolnien podatkowych co do nieruchomości, które są wykorzystywane przez uczelnię do wykonywania tego rodzaju zadań. Działalność spółki celowej stanowi bowiem formę działalności uczeni, o której mowa w art. 149 ust. 1 zd. pierwsze ustawy 2.0, to jest komercjalizacji pośredniej. Celem tego rodzaju aktywności jest obejmowanie lub nabywanie udziałów lub akcji w spółkach lub obejmowanie warrantów subskrypcyjnych uprawniających do zapisu lub objęcia akcji w spółkach, w celu wdrożenia lub przygotowania do wdrożenia wyników działalności naukowej lub know-how związanego z tymi wynikami.

14 Tak wyrok WSA we Wrocławiu z dnia 19 stycznia 2016 r., I SA/Wr 1602/15, LEX nr 2033210.

15 Tekst jednolity: Dz. U. z 2019 r. poz. 1292 z późn. zm. 
Organ w udzielonej odpowiedzi na skargę wniósł o jej oddalenie, podtrzymując argumentację zawartą w zaskarżonej interpretacji. Wojewódzki Sąd Administracyjny w Gorzowie Wielkopolskim w wyroku uchylił zaskarżoną interpretację indywidualną w całości. Przy ponownym rozpoznawaniu sprawy sąd zobligował organ podatkowy do zbadania sposobu i efektów aktywności spółki celowej, przede wszystkim $w$ aspekcie osiągania zysku. Zdaniem sądu ma to znaczenie z uwagi na okoliczności podnoszone przez uczelnię, że spółka świadczy usługi poniżej cen rynkowych (zgodnie z zasadami transferu pomocy do gospodarki). Ponadto sąd nakazał wezwanie uczelni do uzupełnienia wniosku poprzez wskazanie, czy założona przez uczelnię spółka prowadzi na użyczonych przedmiotach działalność gospodarczą. W przypadku potwierdzenia tej okoliczności, konieczne staje się ustalenie zakresu rzeczonej działalności w odniesieniu do konkretnych nieruchomości.

\section{Zwolnienie podatkowe a działalność gospodarcza}

Co do zasady należy zaaprobować kierunek rozważań i argumentację sądu, abstrahując przy tym od wątpliwości wskazanych poniżej na tle lektury uzasadnienia wyroku, powstających na styku z Prawem przedsiębiorców i ustawą 2.0. Naszym zdaniem główna oś problemu związana jest z jednej strony z praktyczną weryfikacją znaczeniową wkomponowanej w konstrukcję zwolnienia podatkowego przesłanki „zajęcia na prowadzenie działalności gospodarczej”, z drugiej natomiast z ustaleniem właściwej współzależności systemowej z przepisami ustawy 2.0 oraz Prawa przedsiębiorców.

Wojewódzki Sąd Administracyjny w Gorzowie Wielkopolskim zasadnie podkreślił, że do przeprowadzenia prawidłowej wykładni art. 7 ust. 2 pkt 1 ustawy o podatkach i opłatach lokalnych niezbędne jest przeprowadzenie analizy w kierunku współistnienia w koniunkcji trzech elementów: podmiotu (uczelni), przedmiotu opodatkowania i oceny zaistnienia stanu „zajęcia” oraz „prowadzenia działalności gospodarczej". W doktrynie i orzecznictwie szeroko podjęto kwestię interpretacji „zajęcia na działalność gospodarczą" ${ }^{16}$. Należy jednak podkreślić, że podstawą

16 M.in. wyrok NSA z dnia 24 maja 2012 r., II FSK 2266/10, LEX nr 1162586; B. Pahl, Glosa do wyroku Naczelnego Sadu Administracyjnego z dnia 24 maja 2012 r., II FSK 2266/10, 2012 [wyd. el. LEX]; L. Etel, S. Presnarowicz, Podatki i opłaty samorzadowe...; W. Morawski, K. Lasiński-Sulecki, O. Łunarski, J. Wantoch-Rekowski, w: T. Brzezicki i in., Podatek od nieruchomości w orzecznictwie sądów administracyjnych. Komentarz. Linie interpretacyjne, Warszawa 2013 [wyd. el. LEX]; R. Dowgier, L. Etel, G. Liszewski, B. Pahl, Komentarz do art. 7, w: tychże, B. Pahl, Podatki i opłaty lokalne... 
do dokonania prawidłowej oceny tej przesłanki jest wydzielenie do badania analitycznego obu pojęć (członów), czyli „zajęcia” oraz „działalności gospodarczej”. Ma to niewątpliwie kluczowe znacznie, bowiem stwierdzenie, że dana aktywność nie stanowi działalności gospodarczej, powoduje, że przesłanka zajęcia przedmiotu opodatkowania (w całości lub części) traci na znaczeniu, skoro aktywność nie jest działalnością gospodarczą. Wypada dodać, że sąd trafnie podkreślił, że chodzi tu nie tylko o określony w ustawie sposób wykorzystywania przedmiotów opodatkowania przez uczelnię, ale i przez osoby trzecie (niebędące adresatami zwolnienia, o którym mowa w art. 7 ust. 2 pkt 1 ustawy o podatkach i opłatach lokalnych), a którym uczelnia oddała przedmiot opodatkowania w posiadanie zależne ${ }^{17}$. Jeśli ten podmiot prowadzi działalność gospodarczą na zajętej nieruchomości, uczelnia $\mathrm{w}$ tym zakresie utraci zwolnienie podatkowe ${ }^{18}$.

\section{3. „Zajęcie na działalność gospodarczą”}

Należy zauważyć, iż ustawa o podatkach i opłatach lokalnych nie definiuje wprost działalności gospodarczej, natomiast w tzw. słowniczku ustawowym odsyła do pojęcia działalności gospodarczej zawartego w Prawie przedsiębiorców. Niestety milczeniem pomija samo pojęcie „zajęcia na działalność gospodarczą", które nie występuje przecież w Prawie przedsiębiorców. Wobec braku legalnej definicji „zajęcia" do odkodowania prawidłowego jego znaczenia należy sięgnąć do znaczenia słownikowego ${ }^{19}$. W tym kontekście można powtórzyć za Wojewódzkim Sądem Administracyjnym w Gorzowie Wielkopolskim, że zajęcie przedmiotu opodatkowania (gruntu, budynku, budowli) na prowadzenie działalności gospodarczej oznacza jego wydzielenie i przeznaczenie na prowadzenie tego rodzaju działalności połączone $\mathrm{z}$ aspektem występowania elementu rzeczywistego wykorzystywania przedmiotu opodatkowania (wykonywanie konkretnych czynności, które mają prowadzić do zamierzonego rezultatu). Wypada także dodać, że „zajęcia na działalność gospodarczą" nie należy utożsamiać z pojęciem „Związania z działalnością gospodarczą", którego ustawa używa, określając zakres przedmiotowy ${ }^{20}$. Niestety także w tym przypadku brak definicji legalnej tego sformułowania. Brak jest też podstaw

17 M.in. wyrok NSA z dnia 21 grudnia 2016 r., II FSK 355/15, LEX nr 2230783; wyrok WSA w Szczecinie z dnia 6 października 2010 r., I SA/Sz 513/10, LEX nr 750369.

18 Wyrok WSA w Poznaniu z dnia 9 lipca 2010 r., III SA/Po 345/10, LEX nr 674920.

19 Słownik języka polskiego [online], https://sjp.pwn.pl/sjp/zajac;2542516.html [dostęp: 9.10.2020 r.].

20 Art. 2 ust. 1 pkt 3 ustawy o podatkach i opłatach lokalnych. 
do przyjęcia reguły, że pojęcia te mogłyby, pomimo odmiennego brzmienia, mieć to samo znaczenie ${ }^{21}$.

W tym kontekście należy pozytywnie - co do zasady - odnieść się do zaleceń sądu dotyczących ustalenia, czy spółka celowa prowadzi na użyczonych przedmiotach działalność gospodarczą oraz na jakich konkretnie nieruchomościach. Uwzględnić przy tym należy, jak słusznie zauważył sąd, że nie jest nieodzowną cechą zajęcia całkowite wyłączenie możliwości prowadzenia na tych nieruchomościach innego rodzaju działalności (działalności badawczej lub naukowej). Nawiązał przy tym do stanowiska Naczelnego Sądu Administracyjnego wyrażonego w wyroku z dnia 22 października 2018 r., II FSK 2533/18²2, dotyczącego kwestii opodatkowania podatkiem od nieruchomości gruntów leśnych ${ }^{23}$.

W naszej ocenie prawidłowe rozstrzygnięcie omawianego problemu uzależnione jest również od ustalenia właściwej korelacji analizowanych zagadnień z przepisami pozapodatkowymi: Prawa przedsiębiorców i ustawy 2.0. Zasadniczo sąd w swoim toku rozumowania podążył w tym kierunku, ale, jak się wydaje, nie był w tym konsekwentny. Uwidacznia się to w świetle analizy treści zaleceń skierowanych do organu, który zobligowany został do ponownego przeprowadzenia postępowania. Można to uznać za podstawowy zarzut wobec wydanego rozstrzygnięcia.

Zgodnie z art. la ust. 1 pkt 4 ustawy o podatkach i opłatach lokalnych działalność gospodarcza zdefiniowana jest w Prawie przedsiębiorców. W analizowanym przypadku bowiem ustawodawca zdecydował się na zastosowanie odesłania systemowego zewnętrznego (do ustawy pozapodatkowej), choć za pożądane uznaje się raczej konstruowanie definicji na zasadzie odesłań wewnątrzsystemowych. Jest to definicja otwarta ${ }^{24}$. Działalność gospodarcza to zorganizowana aktywność zarobkowa, wykonywana we własnym imieniu i w sposób ciągły ${ }^{25}$. Aby dana aktywność została zakwalifikowana do kategorii działalności gospodarczej, konieczne jest więc łączne zaistnienie wskazanych w przepisie cech: zarobkowości, zorganizowania

21 Wynika to z zakazu wykładni synonimicznej, tak też: B. Pahl, Glosa do wyroku...; B. Brzeziński, Podstawy wykładni prawa podatkowego, Gdańsk 2008, s. 49.

22 LEX nr 2599714.

23 Wydaje się, że argumentacja zawarta w przytoczonym wyroku Naczelnego Sądu Administracyjnego może zostać przywołana także w toku narracji dotyczącej podatku od nieruchomości. Wypada jednak wspomnieć, że przywołane orzeczenie zostało wydane na podstawie stanu prawnego obowiązującego przed wprowadzeniem zmian w podatku leśnym po dniu 1 stycznia 2019 r. (art. 1 ust. 4 ustawy o podatku leśnym) w brzmieniu zmienionym przez art. 3 ustawy z dnia 20 lipca 2018 r. (Dz. U. z 2018 r. poz. 1588) zmieniającej m.in. ustawę o podatku leśnym z dniem 1 stycznia 2019 r.

24 A. Gorgol, Działalność gospodarcza jako determinanta podatku od nieruchomości, w: Obrót powszechny i gospodarczy. Problemy podatkowoprawne, red. I. Ramus, Toruń 2014, s. 325-326. 
oraz ciągłości. Brak którejkolwiek z nich jest równoznaczny z przyjęciem, że dana działalność nie stanowi działalności gospodarczej ${ }^{26}$.

Nawiązując do aspektu zarobkowości podejmowanej aktywności, po pierwsze wypada stwierdzić, że niezbędne w tym zakresie jest nastawienie na osiąganie zysku. Chodzi oczywiście o stronę wolitywną działania, bowiem w rzeczywistości wynik podejmowanych działań docelowo nie musi doprowadzić do osiągnięcia dochodu (zarobku) rozumianego jako nadwyżka przychodów nad poniesionymi kosztami. Niemniej jednak, na skutek powstania straty w działalności, określona działalność nie utraci charakteru działalności gospodarczej, jeśli ukierunkowana była na zaspokajanie potrzeb osób trzecich, w sposób racjonalny i gospodarny. Jej charakter nie ulegnie zmianie tak długo, jak długo wykonujący ją będzie miał na względzie osiągnięcie zarobku $\mathrm{z}$ danej aktywności, nawet $\mathrm{w}$ odległej perspektywie czasowej. Tym samym także działalność, która nigdy nie przyniosła prowadzącemu ją podmiotowi dochodu, powinna zostać uznana za zarobkową, o ile była ukierunkowana na uzyskanie takiego dochodu ${ }^{27}$.

Po drugie, nie stanowi działalności gospodarczej działalność wykonywana okresowo i sporadycznie (incydentalnie) ${ }^{28}$. Prowadzenie działalności gospodarczej to działanie stałe, nieokazjonalne, z zarysowanym elementem organizacji, planowania i zawodowości rozumianej jako fachowość, znajomość rzeczy oraz specjalizacja ${ }^{29}$. W kontekście prowadzonych sporów w związku z utratą zwolnień z podatku od nieruchomości przez uczelnie to właśnie ocena w zakresie cechy ciągłości prowadzonej działalności gospodarczej wydaje się być kluczowa. Słusznie więc Wojewódzki Sąd Administracyjny w Gorzowie Wielkopolskim definiując „zajęcie na działalność gospodarczą", dodał, że musi być to działalność wykonywania w sposób trwały (nieincydentalny). Ciągłość wiąże się bowiem z powtarzalnością, regularnym występowaniem i w szczególności trwaniem danej aktywności. Jest przeciwstawiana sporadyczności, okazjonalności i jednorazowości ${ }^{30}$. W orzecznictwie wskazuje się, że do jej zaistnienia konieczny jest określony ciąg powiązanych działań, co nie oznacza jednak konieczności wykonywania działalności w sposób nieprzerwany ${ }^{31}$.

26 Zob. C. Kosikowski, Ustawa o swobodzie działalności gospodarczej. Komentarz, Warszawa 2013.

27 Wyrok SA w Katowicach z dnia 10 stycznia 2020 r., III AUa 424/19, LEX nr 2825691; A.K. Kruszewski, Komentarz do art. 3, w: Prawo przedsiębiorców. Komentarz, red. A. Pietrzak, Warszawa 2019 [wyd. el. LEX].

28 Wyrok NSA z dnia 19 marca 1991 r., II SA 898/90, LEX nr 10283.

29 Wyrok SA w Warszawie z dnia 29 marca 2019 r., III AUa 750/17, LEX nr 2686512.

30 A. Powałowski, Komentarz do art. 2, w: Ustawa o swobodzie działalności gospodarczej. Komentarz, red. A. Powałowski, 2007 [wyd. el. LEX].

31 Postanowienie SA w Szczecinie z dnia 7 sierpnia 2006 r., I ACz 441/06, LEX nr 279953; A.K. Kruszewski, Komentarz do art. 3, w: Prawo przedsiębiorców... 
Po trzecie, cechą pozwalającą odróżnić działalność gospodarczą od innych aktywności jest występowanie elementu zorganizowania. Zgodnie z uzasadnieniem projektu Prawa przedsiębiorców poprzez zorganizowanie należy rozumieć wykorzystanie konkretnych składników materialnych, które są łączone w sensie funkcjonalno-gospodarczym $\mathrm{w}$ jedną uporządkowaną strukturę przy wykorzystaniu której można uczestniczyć w obrocie gospodarczym ${ }^{32}$. W doktrynie wyróżnia się podział na materialny i formalny aspekt zorganizowania działalności gospodarczej. Formalne zorganizowanie działalności gospodarczej odnosi się do czynności o charakterze formalnoprawnym, które związane są z wykonywaniem działalności gospodarczej. Natomiast wypełnienie przesłanek materialnoprawnych wiąże się z podejmowaniem działań mających na celu pozyskanie środków finansowych na prowadzoną działalność, zatrudnienie personelu i zadbanie o warunki lokalowe ${ }^{33}$.

Po czwarte, niezbędne jest zachowanie przesłanki wykonywania działalności we własnym imieniu, a więc działając na własny rachunek, samodzielnie. Jest to działalność charakteryzująca się odrębnością i niezależnością od innych podmiotów prowadzących działalność gospodarczą (niezależność wewnętrzna i zewnętrzna). W przypadku uczelni niezależność wewnętrzna jest uwypuklona przez samego ustawodawcę, który w ustawie 2.0 wskazał wprost, że może ona prowadzić działalność gospodarczą, która jest wyodrębniona organizacyjnie i finansowo ${ }^{34}$.

Wydaje się, że wszystkie powyższe aspekty (ze szczególnym uwzględnieniem zarobkowości i ciągłości) sąd w glosowanym orzeczeniu wziął pod uwagę. Wskazuje na to treść zaleceń, które organ podatkowy powinien uwzględnić przy ponownym rozpatrywaniu sprawy. Rodzi się jednak pytanie, czy ta słuszna co do istoty narracja dotycząca elementów zarobkowości i ciągłości była w ogóle konieczna dla merytorycznego rozpoznania zasadności stosowania zwolnienia podatkowego. W naszej ocenie kluczem do rozwiązania zawisłego sporu rozstrzyganego przez Wojewódzki Sąd Administracyjny jest konfrontacja przepisów podatkowych z przepisami ustawy 2.0 .

32 Rządowy projekt ustawy - Prawo przedsiębiorców z dnia 21 listopada 2017 r., Druk nr 2051, s. 57-58, http://orka.sejm.gov.pl/Druki8ka.nsf/0/9E761CF9B6B03CBCC12581E10059DD88/\%24File/2051. pdf [dostęp: 7.10.2020 r.].

33 A.K. Kruszewski, Komentarz do art. 3, w: Prawo przedsiębiorców... i cytowana tam literatura; wyrok SN z dnia 6 kwietnia 2017 r., II UK 98/16, LEX nr 2307127.

34 Art. 12 ustawy 2.0. Szerzej na temat przesłanek działalności gospodarczej zawartych w Prawie przedsiębiorców zob. np. J. Kiraga, Działalność gospodarcza katolickich szkół wyższych, Folia Iuridica Universitatis Wratislaviensis 2019, t. 8, nr 2, s. 123-126. 


\section{Transfer wiedzy i technologii do gospodarki a zwolnienie podatkowe}

Zgodnie z art. 425 ustawy 2.0 wykonywanie przez uczelnię zadań, o których mowa $\mathrm{w}$ art. 11, oraz prowadzenie działalności sportowej, rehabilitacyjnej lub diagnostycznej nie stanowi działalności gospodarczej w rozumieniu przepisów Prawa przedsiębiorców. Natomiast zgodnie z art. 11 ust. 1 pkt 3 za podstawowe zadanie uczelni ustawa 2.0 uznaje m.in. prowadzenie działalności naukowej, świadczenie usług badawczych oraz transfer wiedzy i technologii do gospodarki. Działalność spółki celowej stanowi bowiem formę działalności uczelni, o której mowa w art. 149 ust. 1 zd. pierwsze ustawy 2.0, tj. komercjalizacji pośredniej, która polega na obejmowaniu lub nabywaniu udziałów lub akcji w spółkach albo obejmowaniu warrantów subskrypcyjnych uprawniających do zapisu lub objęcia akcji w spółkach, w celu wdrożenia lub przygotowania do wdrożenia wyników działalności naukowej lub know-how związanego $\mathrm{z}$ tymi wynikami. Zgodnie z art. 149 ust. 2 ustawy 2.0 uczelnia, w drodze umowy, może powierzyć spółce celowej: zarządzanie prawami do wyników lub do know-how w zakresie komercjalizacji bezpośredniej oraz zarządzanie infrastrukturą badawczą.

W konsekwencji za zasadne można uznać, iż wystąpienie takich okoliczności sprzyja interpretacji pozwalającej na skorzystanie przez uczelnię z preferencji przewidzianej w podatku od nieruchomości. Wydaje się, iż w świetle przywołanych przepisów w zaistniałym stanie faktycznym nie ma potrzeby przeprowadzania dodatkowych ustaleń co do kwestii związanych z zajęciem na działalność gospodarczą w zakresie transferu wiedzy i technologii do gospodarki. Ustawa podatkowa oczywiście uzależnia skorzystanie ze zwolnienia od wykluczenia stanu zajęcia nieruchomości na prowadzenie działalności gospodarczej. Przepisy reformujące szkolnictwo wyższe w Polsce - w przypadku transferu wiedzy i technologii do gospodarki - uznają jednak, że działalność ta nie ma znamion prowadzenia działalności gospodarczej. W takiej sytuacji, w opisanym stanie faktycznym, gdy występuje działalność komercjalizacyjna, należy przyjąć, że na gruncie prawa podatkowego możliwe jest zastosowanie zwolnienia $\mathrm{z}$ opodatkowania.

Niezależnie od tego należy zauważyć, iż zgodnie z art. 149 ust. 4 ustawy 2.0 spółka celowa może prowadzić, jako dodatkową, działalność gospodarczą wyodrębnioną organizacyjnie i finansowo od działalności, o której mowa w ust. 1 tego artykułu (a zatem działalności związanej w głównym nurcie $\mathrm{z}$ komercjalizacją). W świetle tej regulacji konieczne jednak wydaje się przeprowadzenie szczegółowych ustaleń, czy okoliczność ta rzeczywiście ma miejsce poza podstawową aktywnością komercjalizacyjną. W przypadku gdy spółka prowadziłaby tego typu działalność (wyodrębnioną organizacyjnie i finansowo), niemożliwe byłoby zastosowanie zwolnienia 
podatkowego dla uczelni, bowiem nieruchomość (lub jej część) byłaby zajęta na działalność gospodarczą. W glosowanym wyroku ani sąd, ani skarżąca uczelnia nie powoływały się na art. 149 ust. 2 i ust. 4 ustawy 2.0. Wydaje się także, że nawet gdyby przyjąć, że sąd wziął pod uwagę wskazane przepisy w toku swoich rozważań, to sformułowane dla organu zalecenia musiałyby być bardziej zdecydowane i jednoznaczne.

\section{Zakończenie}

W konkluzji wypada w części podzielić tok narracji merytorycznej sądu. Trudno jednak oprzeć się wrażeniu, że nie był on konsekwentny w swoich wywodach i w ostatecznym stanowisku wyrażonym w sentencji wyroku. Nieco wybiórczo ustosunkował się do regulacji nowej ustawy 2.0. Jest to tym bardziej jaskrawe, że strona sugerowała taki kierunek analizy (chociaż, co ma tu istotne znaczenie, nie wskazała konkretnej, właściwej podstawy prawnej w tym zakresie). Sąd wskazał, że w wydanej przez organ interpretacji brak jest rozważań, czy utworzenie spółki, na podstawie art. 149 ust. 1 zd. pierwsze ustawy $2.0 \mathrm{w}$ celu wdrożenia lub przygotowania do wdrożenia wyników działalności naukowej lub know-how związanego z tymi wynikami, nie wyłącza przedmiotu działalności z pojęcia działalności gospodarczej i, co też jest istotne, działalności prowadzonej na przedmiotach wskazanych we wniosku o interpretację. Jak stwierdzono powyżej, działalność komercjalizacyjna (także pośrednia, polegająca na tworzeniu spółek celowych), jako podstawowe zadanie uczelni, wyłączona jest z zakresu działalności gospodarczej uczelni. A zatem okoliczność ta nie musi być oceniana przez organ. Zgodnie natomiast $\mathrm{z}$ art. 149 ust. 4 ustawy 2.0, jeśli spółka celowa prowadzi działalność związaną z transferem wiedzy i technologii do gospodarki, nie jest to działalność gospodarcza. Ta ostatnia bowiem powinna być wyodrębniona organizacyjnie i finansowo. Wydaje się, że działania organu podatkowego powinny być skierowane przede wszystkim na zbadanie, czy taką działalność gospodarczą (wyodrębnioną organizacyjnie i finansowo) spółka celowa prowadzi. 


\section{Bibliografia}

Brzeziński B., Podstawy wykładni prawa podatkowego, Gdańsk 2008.

Etel L., Dowgier R., Liszewski G., Pahl B., Podatki i opłaty lokalne. Komentarz, Warszawa 2020 [wyd. el. LEX].

Etel L., Presnarowicz S., Podatki i opłaty samorządowe. Komentarz, Warszawa 2005 [wyd. el. LEX].

Gorgol A., Działalność gospodarcza jako determinanta podatku od nieruchomości, w: Obrót powszechny i gospodarczy. Problemy podatkowoprawne, red. I. Ramus, Toruń 2014.

Kiraga J., Działalność gospodarcza katolickich szkół wyższych, Folia Iuridica Universitatis Wratislaviensis 2019, t. 8, nr 2.

Kosikowski C., Ustawa o swobodzie działalności gospodarczej. Komentarz, Warszawa 2013.

Kruszewski A.K., Komentarz do art. 3, w: Prawo przedsiębiorców. Komentarz, red. A. Pietrzak, Warszawa 2019 [wyd. el. LEX].

Morawski W., Lasiński-Sulecki K., Łunarski O., Wantoch-Rekowski J., w: T. Brzezicki i in., Podatek od nieruchomości w orzecznictwie sądów administracyjnych. Komentarz. Linie interpretacyjne, Warszawa 2013 [wyd. el. LEX].

Pahl B., Glosa do wyroku Naczelnego Sądu Administracyjnego z dnia 24 maja 2012 r., II FSK 2266/10, 2012 [wyd. el. LEX].

Powałowski A., Komentarz do art. 2, w: Ustawa o swobodzie działalności gospodarczej. Komentarz, red. A. Powałowski, 2007 [wyd. el. LEX].

Zajać, w: Słownik języka polskiego [online], https://sjp.pwn.pl/sjp/zajac;2542516.html [dostęp: 9.10.2020 r.]. 